\title{
Evaluation of Biological Treatability of Soil Contaminated with Manufactured Gas Plant Waste
}

\author{
JON S. GINN, ${ }^{1}$ R.C. SIMS, ${ }^{1}$ and I.P. MURARKA ${ }^{2}$ \\ ${ }^{1}$ Department of Civil and Environmental Engineering \\ Utah State University \\ Logan, UT 84322-4110 \\ ${ }^{2}$ Electric Power Research Institute \\ Palo Alto, CA
}

\begin{abstract}
The biological treatability of subsurface soil contaminated with manufactured gas plant (MGP) waste was evaluated. Mineralization assays incorporating ${ }^{14} \mathrm{C}$-phenanthrene were used to evaluate the biotransformation potential of indigenous microorganisms at the site. Multi-phase laboratory microcosms were used to evaluate the interphase transfer potential and chemical mass distribution of phenanthrene. The Microtox ${ }^{\mathrm{TM}}$ bioassay was used to evaluate detoxification trends at the site. Mineralization results indicated that indigenous microorganisms at the site were capable of transforming phenanthrene, a component of coal-tar creosote. Results also indicated that spiked ${ }^{14} \mathrm{C}$ phenanthrene mineralization was influenced by nutrient addition and by the amount of contamination. The chemical mass distribution of ${ }^{14} \mathrm{C}$-phenanthrene indicated that volatilization may be an important transport mechanism for chemicals residing in, or migrating to the vadose zone of soil. Following removal of the coal-tar waste source at the site, the toxicity of water soluble extracts of the site soil decreased to a non-toxic response based upon Microtox ${ }^{\mathrm{TM}}$ assay results. Parent compound concentrations at the site also decreased with time subsequent to source removal. Results of this study indicate that natural in situ bioremediation may be an important treatment process at a former manufactured gas plant waste site in New York.
\end{abstract}

\section{INTRODUCTION}

The application of wood-preserving, petroleum, and manufactured gas plant (MGP) wastes on soil frequently results in contamination of soil and aquifer material with polycyclic aromatic hydrocarbons (PAHs)[1]. Several PAHs have been identified as carcinogenic and therefore present potential health-related risks with chronic exposure [2]. The biodegradation of phenanthrene (a model three-ring PAH) in liquid cultures by single bacterial species has been demonstrated [3-9]; however, less information is available regarding the biodegradation of phenanthrene or other PAHs in complex coal-tar contaminated aquifers.

The biological treatability of coal-tar contaminated soil and aquifer material is influenced by the extent of contamination. The extent of soil and aquifer contamination requires an evaluation of the aquifer solid phase with regard to hazardous parent chemicals and the natural metabolic potential of indigenous microorganisms to transform target hazardous compounds. The National Research Council (1993), in their recent publication "In situ Bioremediation; When Does it Work?", outlined a strategy combining the collection of field and laboratory data to evaluate the use of in situ bioremediation. The measurement of parent compound disappearance in the field, and the demonstration of the metabolic potential of indigenous microorganisms at a site to transform target parent compounds through laboratory experiments, are primary objectives for evaluating the efficacy of in situ bioremediation [10]. 
To assess in situ PAH biotransformation in a coal-tar contaminated soil, experiments were conducted utilizing ${ }^{14} \mathrm{C}$-phenanthrene. A mineralization assay, developed at Cornell University, was employed using a coal-tar contaminated soil spiked with radiolabeled ${ }^{14} \mathrm{C}$-phenanthrene at $22-24^{\circ} \mathrm{C}$. This study was conducted to evaluate the biodegradability and transformation potential of phenanthrene in contaminated soil from the saturated and unsaturated zone of a manufactured gas plant waste (MGP) site. Additionally, a study was carried out to evaluate the chemical mass balance distribution of ${ }^{14} \mathrm{C}$-carbon resulting from the biotransformation of ${ }^{14} \mathrm{C}$-phenanthrene. The toxicity of aqueous extracts of soil from the site was also determined.

\section{METHODS AND MATERIALS}

\section{Field Samples}

The MGP waste site for this study (EBOS site 24) has been described elsewhere [10]. Soil cores were obtained from EBOS site 24 subsequent to source removal. The source material at the site was removed in the summer of 1991 [11]. Three locations at the site were used for repeated core sampling. A first core was taken in the original source area and designated Station \#1. A second core was taken outside the contaminated plume and designated Station \#2. This core served as the control sample. A third core was taken down-gradient from the original source material (approx. 200 m) [10] within the contaminated plume and designated Station \#19.

\section{Mineralization Assay}

A core sample from each station was obtained aseptically [12] and sampled at three depths: (1) 7.5-9.5 ft below ground surface, (water table interface, WT) (2) 9.5-13.5 ft below ground surface, (saturated zone 1, S1) and (3) 12.5-19.5 ft below ground surface (saturated zone 2, S2). Three grams of soil from each depth in each core were aseptically weighed into $25 \mathrm{ml}$ septum vials (Pierce, Rockford, Illinois). Triplicate vials plus one poisoned control were used for each sediment. Approximately 11000 DPMs of $9-{ }^{14} \mathrm{C}$-phenanthrene (Sigma Corp., St. Louis, MO) and $0.11 \mu g$ of unlabeled phenanthrene (saturated) were added to each vial. To the poisoned controls, $0.5 \mathrm{ml}$ of a $2 \%$ solution of $\mathrm{HgCl}_{2}$ was added. Approximately $0.5 \mathrm{ml}$ of $0.5 \mathrm{~N} \mathrm{NaOH}$ was used as a ${ }^{14} \mathrm{C}-\mathrm{CO}_{2}$ trapping solution and was contained in $15 \times 45 \mathrm{~mm}$ shell vials (VWR Scientific, Greenbelt, MD) placed inside the $25 \mathrm{ml}$ septum vials. The inner vials were elevated above the soil by a glass marble. The base trapping solution was removed with a glass syringe (Hamilton Company, Reno, Nevada) from the $25 \mathrm{ml}$ septum vials on days $1,2,5,8$ and 19 and analyzed for evolved ${ }^{14} \mathrm{C}-\mathrm{C}_{2}$ using a Beckman (Model LS $6000 \mathrm{SE}$ ) liquid scintillation counter (Beckman Instruments, Redmond, Washington). Fresh base trapping solution was added subsequent to each sampling period. Incubations were carried out at $20-22^{\circ} \mathrm{C}$ in the dark.

\section{Chemical Mass Distribution}

The biotransformation and chemical mass balance distribution of added ${ }^{14} \mathrm{C}$-phenanthrene in site soil was evaluated using a Biomieter flask [13] system. A pproximately $50 \mathrm{~g}$ of soil from station \#2 (depth $2 \mathrm{ft}$.) were added to seven separate biometer flasks. The moisture content of the soil was determined to be approximately $15 \%$ dry wt. Nutrient analysis of the soil was carried out by Cornell University in 1989 [10] and showed available $\mathrm{NH}_{3}$ and $\mathrm{NO}_{3}$ in the unsaturated zone to be less than 9 $\mathrm{mg} / \mathrm{Kg}$, combined. Each of the seven microcosms was spiked with $20 \mu \mathrm{Ci} / \mathrm{Kg}$ (wet weight) of 9-

${ }^{14} \mathrm{C}$-phenanthrene (Sigma Corp., St. Louis, MO) and $200 \mathrm{mg} / \mathrm{Kg}$ of unlabeled phenanthrene. One microcosm served as a control and was poisoned by saturating the soil with a $2 \% \mathrm{HgCl}_{2}$ solution. Evolved ${ }^{14} \mathrm{C}-\mathrm{CO}_{2}$ was trapped in $10 \mathrm{ml}$ of $0.1 \mathrm{~N} \mathrm{KOH}$ held in the side arm of each biometer flask. A $60 \mathrm{ml}$ syringe was used to remove and replenish the base trapping solution from the side arm of the biometer flask. Aeration of each biometer microcosm was achieved by drawing $150 \mathrm{ml}$ of fresh air through the system at each sampling period with the syringe. The fresh air was passed through an ascarite column, mounted on top the biometer flask, to remove $\mathrm{CO}_{2}$ prior to aeration. This aeration 
procedure also enhanced the entrapment of any volatile ${ }^{14} \mathrm{C}$ within the polyurethane plug for subsequent analysis.

Analysis of evolved ${ }^{14} \mathrm{C}-\mathrm{CO}_{2}$ was carried out by evacuating the $10 \mathrm{ml}$ trapping solution and analyzing $1 \mathrm{ml}$ portions (diluted to $10 \mathrm{ml}$ with scintillation cocktail) using a Beckman (Model LS $6000 \mathrm{SE}$ ) liquid scintillation counter (Beckman Instruments, Redmond, Washington). Fresh $\mathrm{CO}_{2}$ trapping solution was replaced in the side arm of the biometer flask after each sampling. At day 17, three biometer flask microcosms (S1, S2, S3 Table 1) were sacrificed to determine the distribution of ${ }^{14} \mathrm{C}$-carbon among phases within the biometer system. The chemical mass distribution was determined by measuring: 1) cumulative ${ }^{14} \mathrm{C}-\mathrm{CO}_{2}$ evolved, 2) volatilized ${ }^{14} \mathrm{C}$-carbon in the polyurethane foam plug, 3) solvent extractable ${ }^{14} \mathrm{C}$-carbon in the soil, and 4) non-solvent extractable ${ }^{14} \mathrm{C}$-carbon in the soil. The remaining four microcosms, including the poisoned control, were sacrificed at day 65. A summary of the experimental matrix is given in Table 1.

Volatilized ${ }^{14} \mathrm{C}$-carbon was Soxhlet extracted from the polyurethane plug associated with each biometer flask, with approximately $250 \mathrm{ml}$ of methylenechloride/acetone (1:1 vol:vol) for 16-24 hours. The solvent extract was then condensed to approximately $1.5 \mathrm{ml}$ and brought to a final volume of $10 \mathrm{ml}$ in acetonitrile. A portion $(1 \mathrm{ml})$ from each organic plug extract was mixed with approximately $10 \mathrm{ml}$ of scintillation cocktail and counted by liquid scintillation.

TABLE 1

Experimental matrix for chemical ${ }^{14} \mathrm{C}$-carbon mass distribution study.

\begin{tabular}{lllc}
\hline Sample & Abbreviation & Definition & Sacrificed on Day \\
\hline 1 & S1 & Microcosm 1 & 17 \\
2 & S2 & Microcosm 2 & 17 \\
3 & S3 & Microcosm 3 & 17 \\
4 & UN & Unamended microcosm & 65 \\
5 & NP1 & Microcosm with nitrogen and & 65 \\
& & phosphorous addition at day & \\
& & $39:(20 \mathrm{mg}-\mathrm{N} / \mathrm{Kg}, 1.0 \mathrm{mg}-$ & \\
6 & NP2 & Microcosm with nitrogen and & 65 \\
& & phosphorous addition at day & \\
& & $39:(14 \mathrm{mg}-\mathrm{N} / \mathrm{Kg}, 1.0 \mathrm{mg}-$ & \\
7 & & P/Kg) & 65 \\
\hline
\end{tabular}

The solvent extractable ${ }^{14} \mathrm{C}$-carbon was determined by extracting the soil phase of each biometer flask with methylenechloride/acetone $(1: 1 \mathrm{vol}: \mathrm{vol})$ for 6 minutes using a sonication probe (Heat Systems, Inc., Farmingdale, NY). The solvent extract was then condensed to approximately $1.5 \mathrm{ml}$ and brought to a final volume of $10 \mathrm{ml}$ in acetonitrile. A portion $(1 \mathrm{ml})$ from each solvent extract was mixed with approximately $10 \mathrm{ml}$ of scintillation cocktail and counted by liquid scintillation.

Non-solvent extractable residues of ${ }^{14} \mathrm{C}$-carbon were analyzed by combusting (in triplicate) $1.5 \mathrm{~g}$ portions of soil from each biometer flask microcosm. Samples were combusted at $900^{\circ} \mathrm{C}$ using a Biological Oxidizer OX600 (R.J. Harvey Instrument Corp., Hillsdale, New Jersey). Liberated ${ }^{14} \mathrm{C}$ carbon was trapped in a $20 \mathrm{ml}$ solution containing, on a volume to volume basis, $50 \%$ ready gel (Beckman Ready Gel, Beckman Inst., Redmond, Washington), 40\% reagent grade methanol, and $10 \%$ reagent grade monoethanolamine. The radioactivity trapped in the total volume of trapping solution was counted by liquid scintillation.

\section{Toxicity}

Toxicity trends associated with the extent of contamination at the site were determined by: 1) evaluating the mineralization potential of indigenous microorganisms in highly contaminated soil and 2) performing Microtox ${ }^{\mathrm{TM}}$ analysis of aqueous soil extracts from soil core material from station \#19 at two points in time (1991 and 1993) subsequent to source removal. 
Mineralization activity was evaluated in four additional microcosms containing contaminated soil from station \#19. A soil core taken 1991 revealed a distinct zone of highly contaminated soil from 4 to 8 feet below the ground surface. Soil at this depth was darker in color compared to soil either above or below this level. The zone of high contamination contained phenanthrene at a concentration of approximately $300 \mathrm{mg} / \mathrm{kg}$, compared to $3 \mathrm{mg} / \mathrm{kg}$ at a depth of approximately 10 feet [14]. Approximately $50 \mathrm{~g}$ of soil was taken in duplicate from within the highly contaminated zone, and below in the lightly contaminated zone at a depth of approximately $10 \mathrm{feet}$. Each microcosm was spiked with $20 \mu \mathrm{Ci} / \mathrm{Kg}$ (wet weight) of 9-14 C-phenanthrene (Sigma Corp., St. Louis, MO) and incubated at $30^{\circ} \mathrm{C}$. Evolved ${ }^{14} \mathrm{C}-\mathrm{CO}_{2}$ was trapped in $10 \mathrm{ml}$ of $0.1 \mathrm{~N} \mathrm{KOH}$ held in the side arm of each biometer flask. Mineralization was evaluated as described for the chemical mass distribution study, however, the distribution of the ${ }^{14} \mathrm{C}$-phenanthrene within these four microcosms was not determined.

The Microtox TM bioassay was used to measure the extent of detoxification of contaminated core material from within the plume which had occurred after source removal. The Microtox bioassay utilizes the marine organism Photobacterium phosphoreum as a test organism. The Microtox measures the reduction in light output of test organisms when challenged by varying concentrations of aqueous samples as an indication of the degree of toxicity of a particular sample. Approximately $25 \mathrm{~g}$ of soil, taken from 4-8 $\mathrm{ft}$ depth at Station \#19, was extracted with $100 \mathrm{ml}$ of distilled-deionized water for 16-24 hr in duplicate on a rotary tumbler at $30 \mathrm{rpm}$. The samples were allowed to settle for twenty-four hours prior to analysis. The effective concentration of aqueous sample causing a reduction in light output by $50 \%$ is called the EC 50 . The lower the EC 50 value, the higher the degree of toxicity or inhibition caused by the organic constituents within the aqueous extract. EC 50 values greater than 100 are considered non-toxic. EC 50 values were determined for soil from station \#19 taken in 1991 and 1993.

\section{RESULTS AND DISCUSSION}

\section{Mineralization Assay}

Cumulative $\%{ }^{14} \mathrm{C}-\mathrm{CO}_{2}$ production curves for the mineralization of ${ }^{14} \mathrm{C}$-phenanthrene in site soil from each station and depth are presented in Figures 1-3. Mineralization of ${ }^{14} \mathrm{C}$-phenanthrene indicated the potential for the formation of intermediate or biotransformation products by the indigenous microbial population in coal tar contaminated soil. The lack of an observed lag period indicates that aquifer material from each bore hole appears to have microorganisms that are capable of biodegrading PAH. The low cumulative evolved ${ }^{14} \mathrm{CO}_{2}(<3.5 \%$ for replicates $1-3)$ from Station $\# 2$, saturated zone 2 , may have resulted from oxygen or nutrient limitations or the population of microorganisms being unable to adapt and transform phenanthrene.

Cumulative ${ }^{14} \mathrm{C}-\mathrm{CO}_{2}$ at each station depth was evaluated by computing the mean and standard deviation of triplicate measurements. For each mean and standard deviation, evolved ${ }^{14} \mathrm{C}-\mathrm{CO}_{2}$ in poisoned controls are shown in parenthesis. Mineralization of phenanthrene in sediments from the restored source area, Station \#1 (Figure 1), did not vary significantly with depth (Figure 1 a, b, c). Mineralization at the water table interface $(8.5 \mathrm{ft})$, saturated zone $1(14.5 \mathrm{ft})$, and saturated zone 2 $(19.0 \mathrm{ft})$ was observed to be $32 \pm 0.5 \%(4.9 \%), 29.9 \pm 7.7 \%(5.1 \%)$, and $33.4 \pm 1.2 \%$ (3.3\%) respectively.

Mineralization of phenanthrene in sediments from Station \#2 (Figure 2) appears to vary with depth. Mineralization of $24.5 \pm 6.2 \%(8.1 \%)$ was observed at the water table interface depth of 7.5 $\mathrm{ft}$. Mineralization of $16.7 \pm 0.8 \%(14.2 \%)$ was observed at the saturated zone 1 depth of $13.5 \mathrm{ft}$. At the lowest depth of Station \#2, $17.8 \mathrm{ft}$., mineralization of $2.6 \pm 0.7 \%(3.0 \%)$ was observed.

Mineralization of phenanthrene in sediments from within the contaminated plume area, Station \#19 (Figure 3), was observed to decrease to the lowest with depth. Mineralization at the water table interface $(9.7 \mathrm{ft})$, saturated zone $1(15.5 \mathrm{ft})$, and saturated zone $2(19.5 \mathrm{ft})$ was observed to be $28.9 \pm$ $2.5 \%(5.0 \%), 27.7 \pm 10.2 \%(7.0 \%)$, and $15.9 \pm 2.5 \%(11.1 \%)$ respectively.

The mineralization activity of each core and depth was evaluated using a first order kinetic model. The rates of mineralization for each core and depth are presented in Table 2 . The mineralization activity, evidenced by ${ }^{14} \mathrm{CO}_{2}$ production, was found in general, to decrease with depth. The distribution of mineralization activity with depth has also been supported by other 
researchers working jointly on the same site [10]. Madsen et al., (1991) observed the decline in microscopic and viable counts of bacteria with depth below the water table [10], which may account for the observed decrease in mineralization rate with depth.

(a)

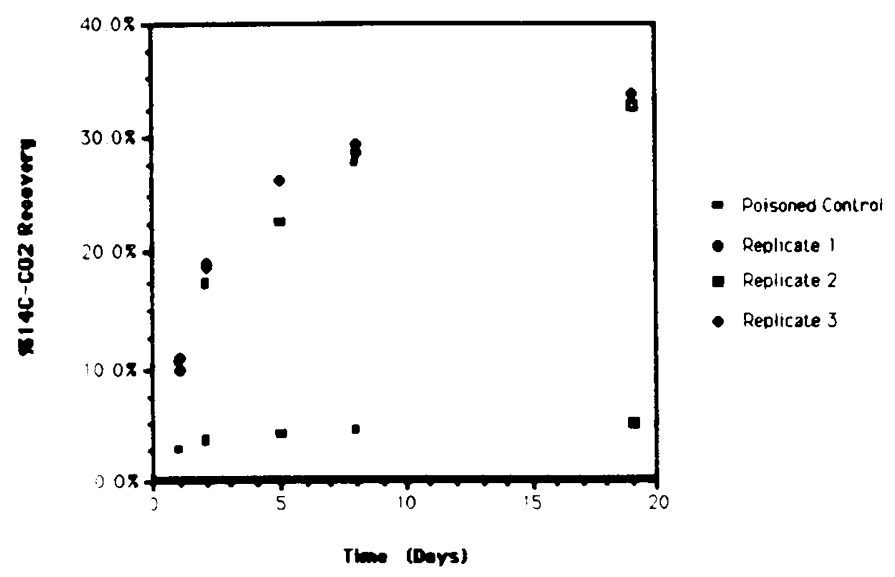

(b)

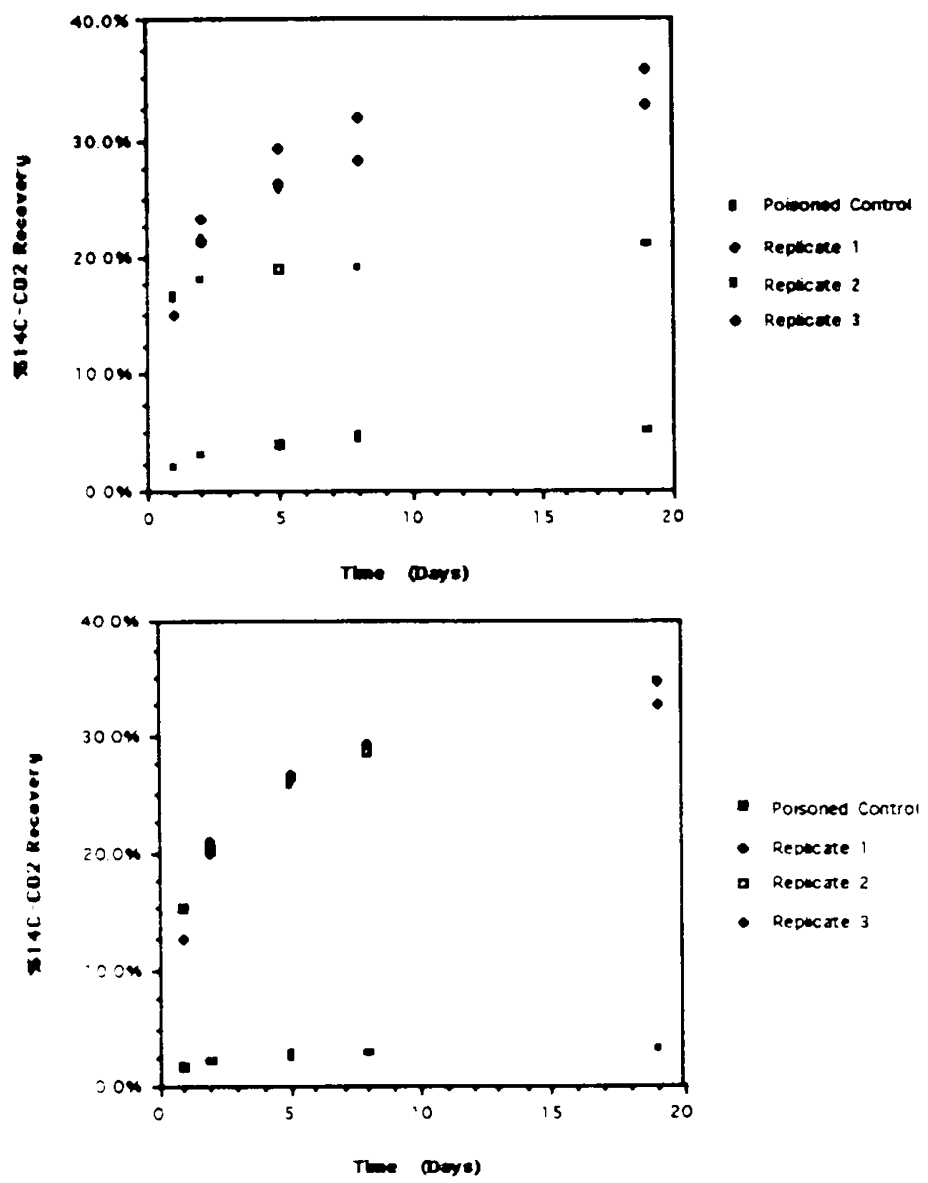

FIGURE 1

Evolved ${ }^{14} \mathrm{CO}_{2}$ during partial mineralization of ${ }^{14} \mathrm{C}$-phenanthrene of Station \#1 sediments at three depths; a) water table, depth $8.5 \mathrm{ft}$, b) saturated zone 1, depth $14.5 \mathrm{ft}$, and c) saturated zone 2, depth $19.0 \mathrm{ft}$. 
(a)

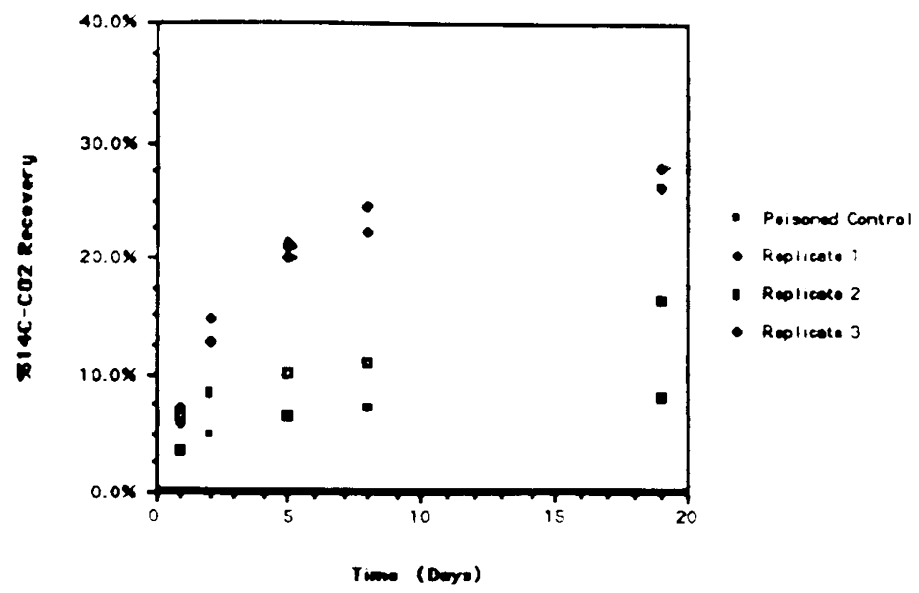

(b)

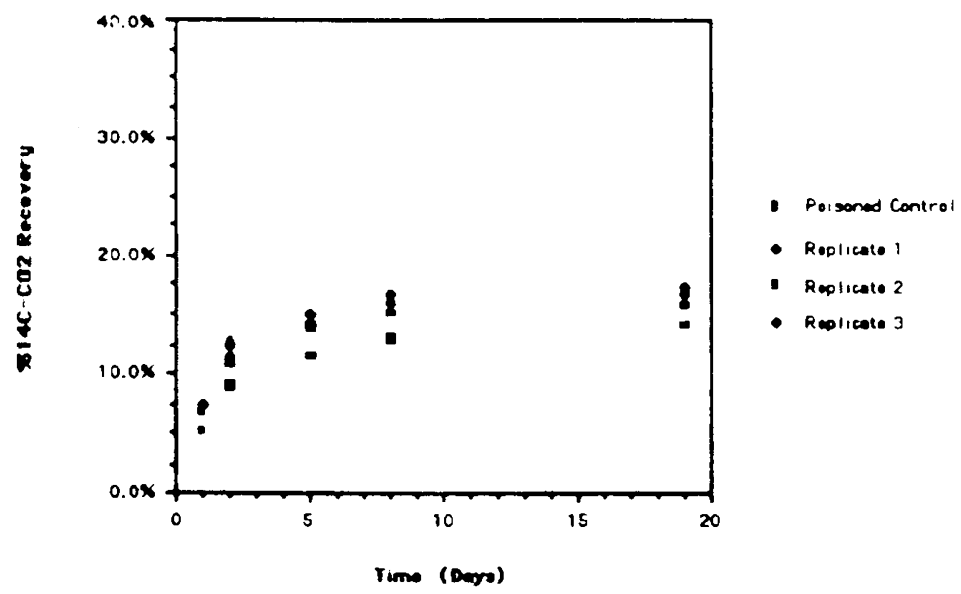

(c)

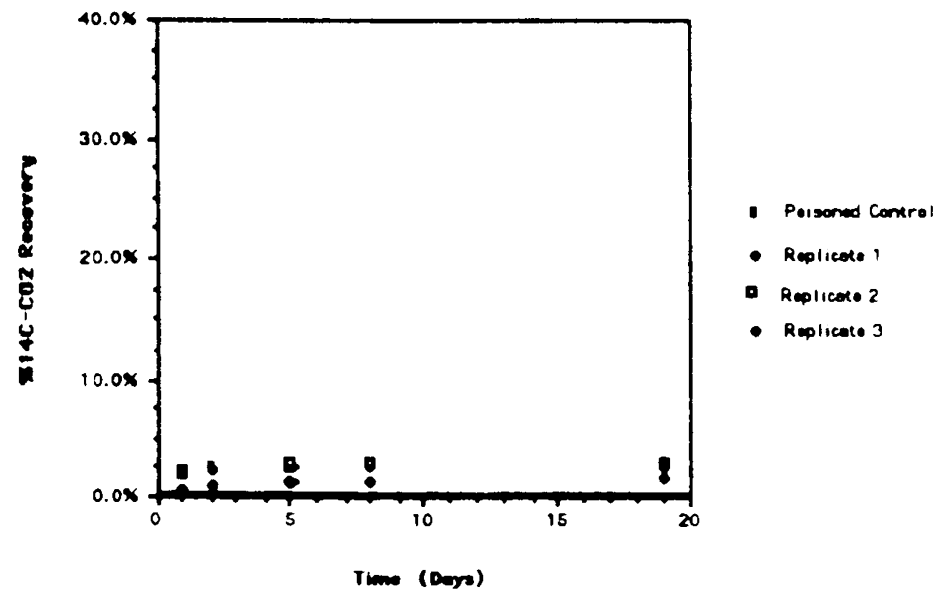

FIGURE 2

Evolved ${ }^{14} \mathrm{CO}_{2}$ during partial mineralization of ${ }^{14} \mathrm{C}$-phenanthrene of Station \#2 sediments at three depths; a) water table, depth $7.5 \mathrm{ft}$, b) saturated zone 1, depth $13.5 \mathrm{ft}$, and c) saturated zone 2, depth $17.8 \mathrm{ft}$. 
(a)

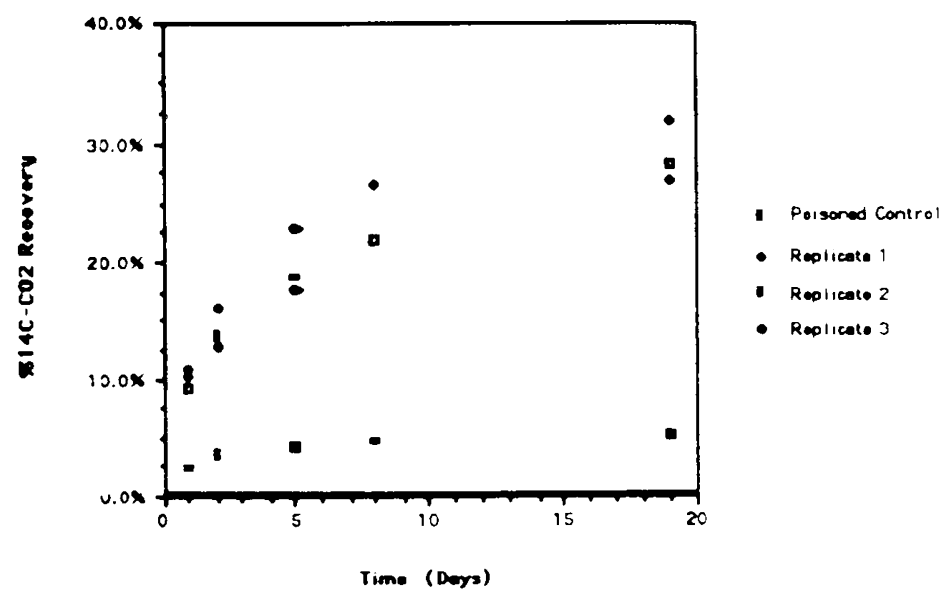

(b)

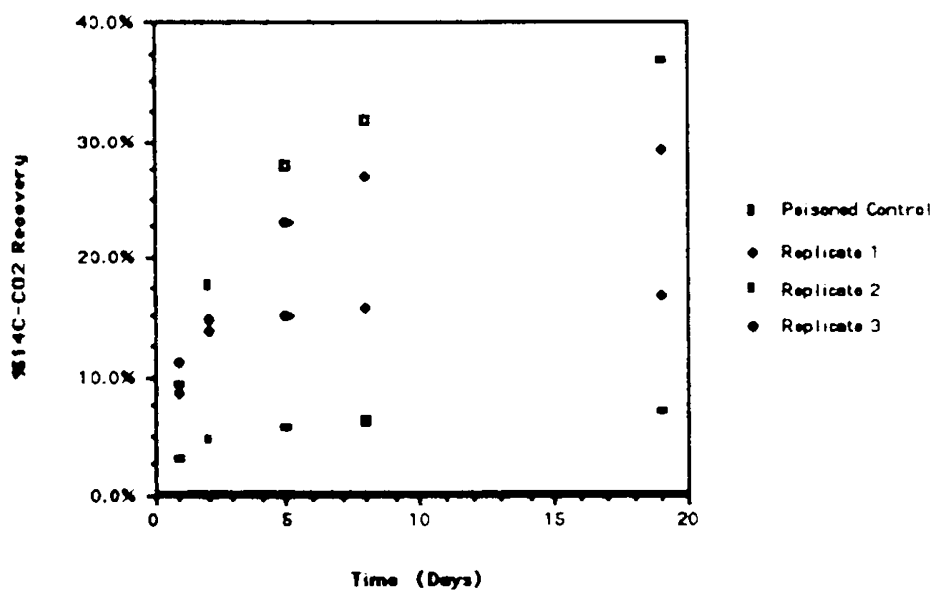

(c)

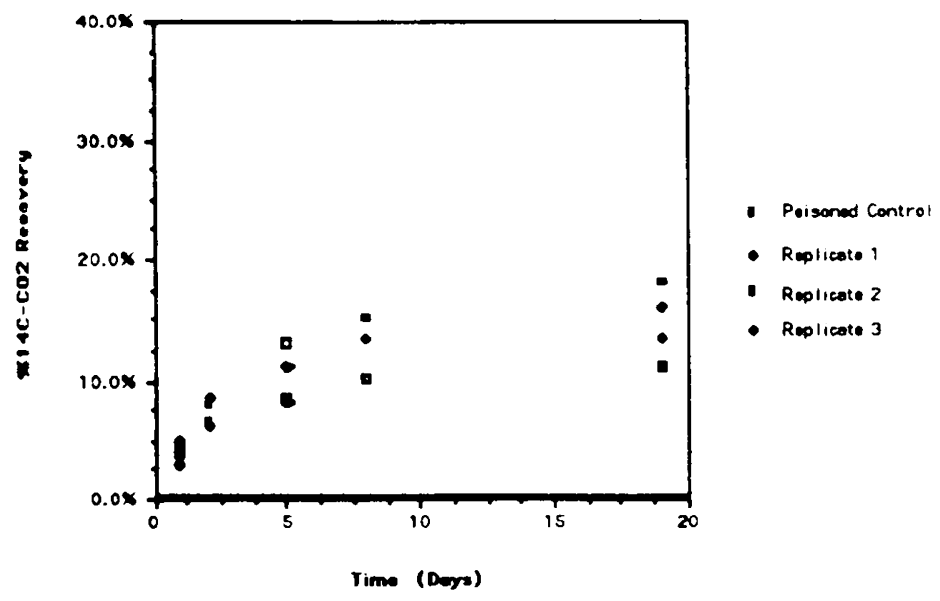

FIGURE 3

Evolved ${ }^{14} \mathrm{CO}_{2}$ during partial mineralization of ${ }^{14} \mathrm{C}$-phenanthrene of Station \#19 sediments at three depths; a) water table, depth $9.7 \mathrm{ft}, \mathrm{b}$ ) saturated zone 1, depth $15.5 \mathrm{ft}$, and c) saturated zone 2, depth $19.5 \mathrm{ft}$. 
TABLE 2

First order mineralization rates of ${ }^{14} \mathrm{C}$-phenanthrene for each core and depth (\%/day) with upper and lower $95 \%$ confidence intervals in parenthesis.

\begin{tabular}{|c|c|c|c|}
\hline Depth & Station \#1 & Station \#2 & Station \#19 \\
\hline $\begin{array}{l}\text { Water Table } \\
(7.5-9.5 \mathrm{ft})\end{array}$ & $1.5(0.004,3.0)$ & $1.0(0.1,2.0)$ & $1.3(0.4,2.1)$ \\
\hline $\begin{array}{l}\text { Saturated zone } 1 \\
(9.5-13.5 \mathrm{ft})\end{array}$ & $0.9(.009,1.8)$ & $0.5(0.2,1.2)$ & $1.1(0.1,2.4)$ \\
\hline $\begin{array}{l}\text { Saturated zone } 2 \\
(12.5-19.5 \mathrm{ft})\end{array}$ & $1.4(0.2,2.5)$ & $0.05(0.01,0.1)$ & $0.7(0.1,1.3)$ \\
\hline
\end{tabular}

\section{Chemical Mass Distribution}

Biodegradation is often assessed by evaluating the disappearance of target hazardous compounds $[3,15]$. However, evaluation of the interphase transfer rates in a multi-phase subsurface environment can provide information for assessing other important mechanisms for loss of parent compounds [16]. A chemical mass distribution was carried out on seven microcosms, containing 50 grams each of soil, from the unsaturated zone (Station $\# 2-2 \mathrm{ft}$ depth) spiked with $9-14 \mathrm{C}$-phenanthrene. Less than $0.15 \%$ mineralization of the added phenanthrene was observed through 17 days of incubation, for all samples, at $30^{\circ} \mathrm{C}$ (Figure $4 \mathrm{a}, \mathrm{b}$ ).

(a)

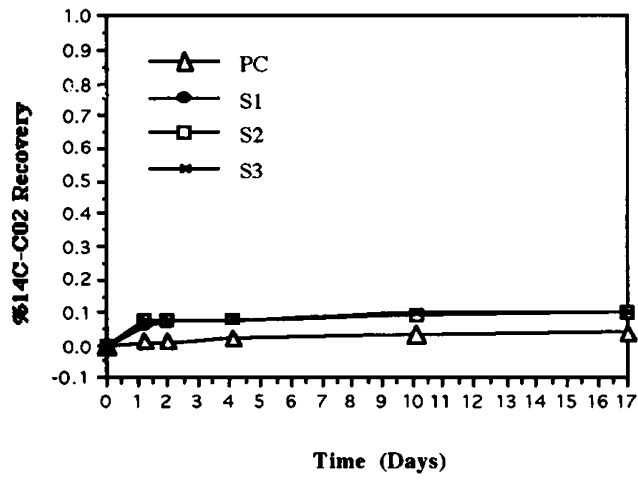

(b)

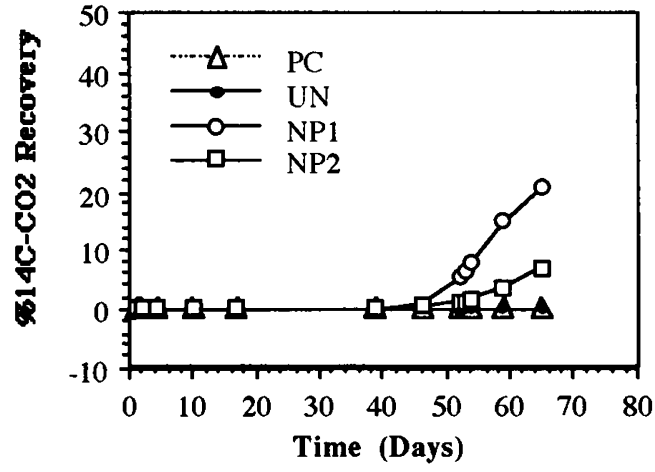

FIGURE 4

Evolved ${ }^{14} \mathrm{C}-\mathrm{CO}_{2}$ versus time for EBOS Site 24 (Control) soil spiked with $20 \mu \mathrm{Ci} / \mathrm{kg}$ (9)- ${ }^{14} \mathrm{C}$ phenanthrene through a) 17 days and b) 65 days. 


\section{TABLE 3}

Distribution of ${ }^{14} \mathrm{C}$-carbon in microcosms sacrificed at 17 days and microcosms sacrificed at 65 days.

\begin{tabular}{ccccccc}
\hline Sample & $\begin{array}{c}\text { Time } \\
\text { (Days) }\end{array}$ & $\begin{array}{c}\text { Organic Plug } \\
\text { Extract }\end{array}$ & $\begin{array}{c}\text { Solvent } \\
\text { Extract }\end{array}$ & $\begin{array}{c}\text { Soil } \\
\text { Combustion }\end{array}$ & ${ }^{14}{\mathrm{C}-\mathrm{CO}_{2}}_{2}$ & Total \\
\hline S1 & 17 & 30.68 & 55.60 & 4.98 & 0.098 & 91.35 \\
S2 & 17 & 26.45 & 58.41 & 6.41 & 0.097 & 91.37 \\
S3 & 17 & 28.84 & 58.17 & 5.14 & 0.099 & 92.25 \\
UN & 65 & 53.18 & 32.94 & 3.91 & 0.13 & 90.16 \\
NP1 & 65 & 51.94 & 4.41 & 11.02 & 20.45 & 87.82 \\
NP2 & 65 & 56.32 & 12.05 & 5.77 & 6.90 & 81.04 \\
PC & 65 & 56.29 & 14.57 & 4.39 & 0.06 & 75.31 \\
\hline
\end{tabular}

At 17 days, three microcosms were sacrificed to evaluate the distribution of ${ }^{14} \mathrm{C}$-carbon. The mass balance results are presented in Table 3. The majority (approx. 57\%) of the added label was observed in the solvent extractable phase while approximately $28 \%$ of the added radiolabeled carbon was found in the organic plug extract. The remaining fraction obtained by combusting the soil, was found to contain $5.5 \%$ of the total radiolabeled carbon. At day $65, \mathrm{NP1}, \mathrm{NP2}, \mathrm{PC}$ and UN microcosms were sacrificed to obtain a mass distribution of ${ }^{14} \mathrm{C}$-carbon. The results of the mass distribution are presented in Table 3.

Volatilized ${ }^{14} \mathrm{C}$-carbon for microcosms receiving added nutrients was observed to be $51-56 \%$. The organic plug extracts of the poisoned control and unamended microcosm contained $56-53 \%{ }^{14} \mathrm{C}$, respectively. Volatilization of ${ }^{14} \mathrm{C}$-carbon increased from over $25 \%$ (S1-S3) at day 17 , to over $50 \%$ (PC, NP1, NP2 and UN) at day 65. Therefore, volatilization appears to play a dominating role in the distribution of the ${ }^{14} \mathrm{C}$-carbon within all microcosms at $30^{\circ} \mathrm{C}$.

In addition to volatilization, sorption of target compounds to soil material influences the fate of hydrophobic organic compounds in subsurface environments [17]. In this study, sorption was assessed by quantifying ${ }^{14} \mathrm{C}$-carbon remaining on the soil (soil combustion) subsequent to solvent extraction. ${ }^{14} \mathrm{C}$-carbon bound to the soil accounted for less than $7 \%$ of the total radiolabeled carbon added in all samples, with the exception of NP1, where $11 \%$ of the radiolabeled carbon was bound to the soil. The sorption of organic compounds to soil can affect the rate of biodegradation $[18,19]$. Microbial uptake rates can be limited by slow-desorption since only compounds in the non-sorbed state are typically subject to microbial attack [20].

The rate limiting step in the microbial uptake and subsequent mineralization of phenanthrene in this study, appears to be $\mathrm{N}$ and $\mathrm{P}$ availability. At day 39 , nitrogen and phosphorus were added to microcosm NP1 and NP2, resulting in partial mineralization of $9-14 \mathrm{C}$-phenanthrene $(20 \%-6 \%$, Figure 4 b).

\section{Toxicity Evaluation}

Mineralization of ${ }^{14} \mathrm{C}$-phenanthrene was also used to evaluate the toxicity of lightly and heavily contaminated soil. Soil from Station \#19 containing a distinct zone of high contamination approximately 4 to 8 feet below the ground surface was evaluated for the mineralization potential of indigenous microorganisms. Lightly contaminated soil amended with nutrients resulted in cumulative $\%{ }^{14} \mathrm{C}-\mathrm{CO}_{2}$ production in the range of $25-30 \%$ after 5 days of incubation at $30^{\circ} \mathrm{C}$. Results are presented in Figure 5. The highly contaminated soil microcosm yielded no $\%{ }^{14} \mathrm{C}-\mathrm{CO}_{2}$ production. Inhibition of mineralization in the highly contaminated soil is attributed to a toxic effect of creosote on the soil microbial population.

The Microtox assay was used to evaluate changes in toxicity with time of core material from the site. EC50 values were determined for core material at Station \#19 taken at two different sampling periods in 1991 and 1993, respectively. The results of the Microtox analysis are given in Table 4. The aqueous extracts of the soil core material from 1991 samples yielded a toxic response to the Microtox organisms $(\mathrm{EC} 50=17.5)$. Analyzing aqueous extracts from soil core material from the same location in 1993 resulted in a non-toxic response to the Microtox ${ }^{\mathrm{TM}}$ organisms. The observed trend towards detoxification may have been influenced by the removal of the source material in 1991 . The removal of the source material was followed by an observed decrease in plume concentrations of naphthalene and phenanthrene [21]. Decreases in toxicity are probably caused by the removal of 
source material entering the plume and the occurrence of in situ biodegradation. Dilution through groundwater flow and recharge may have also influenced toxicity trends at the site.

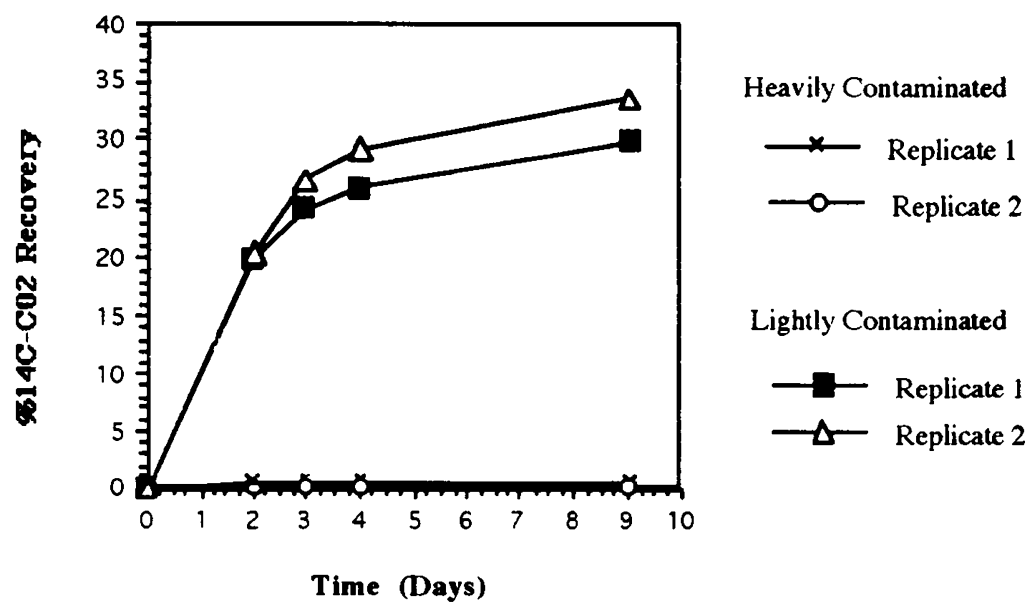

FIGURE 5

Evolved ${ }^{14} \mathrm{CO}_{2}$ from laboratory microcosms, spiked with ${ }^{14} \mathrm{C}$-phenanthrene, containing heavily contaminated and lightly contaminated soil from Station \#19.

TABLE 4

Microtox EC50 results from aqueous extracts of soil within the contaminated

plume area at Station \#19.

\begin{tabular}{lll}
\hline SAMPLE & EC50 & $\mathrm{pH}$ \\
\hline Station \#19(1991) & 17.5 & 6.5 \\
Station \#19(1993) & NT & 6.5 \\
Station \#2 (1993) & NT & 6.7 \\
\hline
\end{tabular}

NT-non toxic (EC50 value greater than 100)

\section{CONCLUSIONS}

Field and laboratory results from this research provide evidence that natural in situ bioremediation is an important treatment process at a former manufactured gas plant waste site in New York. Indigenous soil microorganisms at the site exhibited the potential to transform phenanthrene, a known component of coal tar creosote. The production of ${ }^{14} \mathrm{C}-\mathrm{CO}_{2}$ from ${ }^{14} \mathrm{C}$-labeled phenanthrene indicated that metabolic intermediates may be produced through the oxidation of phenanthrene. This research indicated that microorganisms in both contaminated and uncontaminated soil are capable of transforming phenanthrene in the site soil.

Chemical mass distribution studies using laboratory microcosms indicated that volatilization and nutrient availability may play important roles in the biotreatment of contaminated soil at the site. Reliance on disappearance of parent compounds as an estimate of biodegradation may over-estimate transformation due to natural biological processes. Interphase transfer potential of chemicals in a multiphase subsurface environment should be evaluated.

Microbial processes responsible for biodegradation were inhibited in highly contaminated soil containing coal-tar creosote. Engineering approaches such as source removal can enhance natural bioremediation processes by stopping the introduction of toxic chemicals at a site. Biotransformation products may be more toxic or less toxic than target parent compounds. Examining aqueous extracts of soil core material using the Microtox ${ }^{\mathrm{TM}}$ assay provided a simple field measure of toxicity trends at the site and indicated decreasing toxicity with time following source removal. 
Monitoring parent compound concentrations and toxicity trends at a site are field measurements useful in evaluating the efficacy of in situ bioremediation. Concurrently, laboratory experiments may be employed to evaluate: (1) the potential of indigenous microorganisms to transform target compounds such as PAH, (2) the influence of nutrients, and (3) the interphase transfer potential of target compounds and transformation products. These field measurements and laboratory assays provide information useful for site characterization and are congruent with the National Research Council's strategy for evaluation of in situ biotreatment of contaminated soils.

\section{ACKNOWLEDGMENTS}

This work was supported by the Electric Power Research Institute (EPRI), Palo Alto, California, through a competitive contract [Agreement No. RP2879-09, "Biotransformation Studies of Organic Substances"] to Utah State University, Logan, UT. Dr. Ronald C. Sims was the principal investigator and Dr. Ishwar Murarka was the EPRI Project Officer.

\section{REFERENCES}

1. Lee, L.S., P.S. Rao, and 1. Okuda, Equilibrium Partitioning of Polycyclic Aromatic Hydrocarbons from Coal Tar into Water. Environmental Science and Technology, 1992. 26(11): p. 2110-2115.

2. Williams, G.M. and J.H. Weisburger, Chemical Carcinogens, in Casarett and Doull's Toxicology, M.O. Amdur, J. Doull, andC.D. Klaassen, Editor. 1991, McGraw Hill:

3. Sherrill, T.W. and G.S. Sayler, Phenanthrene biodegradation in freshwater environments. Applied and Environmental Microbiology, 1980. 39(1): p. 172-178.

4. Guerin, W.F. and G.E. Jones, Two-stage mineralization of phenanthrene by estuarine enrichment cultures. Applied and Environmental Microbiology, 1988. 54(4): p. 929-936.

5. Guerin, W.F. and G.E. Jones, Mineralization of phenanthrene by a Mycobacterium sp. Applied and Environmental Microbiology, 1988. 54(4): p. 937-944.

6. Heitkamp, M.A., W. Franklin, and C.E. Cerniglia, Microbial metabolism of polycyclic aromatic hydrocarbons: isolation and characterization of a pyrene-degrading bacterium. Applied and Environmental Microbiology, 1988. 54(10): p. 2549-2555.

7. Keuth, S. and H.J. Rehm, Biodegradation of phenanthrene by Arthrobacter polychromogenes isolated from a contaminated soil. Applied Microbiology and Biotechnology, 1991. 34: p. 804808.

8. Strandberg, G.W., T.J. Abraham Jr., and G.C. Frazier, Phenanthrene degradation by Beijerinckia sp. Biotechnology and Bioengineering, 1989. 28: p. 142-145.

9. Weissenfels, W.D., M. Beyer, and K. Jurgen, Degradation of phenanthrene, fluorene and fluoranthene by pure bacterial cultures. Applied Microbiology and Biotechnology, 1990. 32: p. 479-484.

10. Madsen, E.L., S.N. Levinc, and W.C. Ghiorse, Microbiology of a Coal-Tar Disposal Site: A Preliminary Assessment. EPRI EN-7319, Project 2879-5, Final Report, 1991. .

11. EPRI, Long-Term Groundwater Monitoring Study at EBOS Site 24. Land and Water Quality News, 1993. 7(2): p. 8-12.

12. Madsen, E.L. and W.C. Ghiorse, Biotransformation of Organic Substances. 1993, Cornell University:

13. Bartha, R. and D. Pramer, Features of a flask and method for measuring the persistence and biological effects of pesticides in soil. Soil Science, 1965. 100: p. 68-70.

14. Ginn, J.S., R.C. Sims, and I.P. Murarka. Evaluation of In Situ Bioremediation Associated with 
Natural Attenuation at a Gas Plant Waste Site. in In Situ and On-Site Bioreclamation: The Third International Symposium Proceedings (in review). 1994.

15. Bauer, J.E. and D.G. Capone, Degradation and mineralization of the polycyclic aromatic hydrocarbons anthracene and naphthalene in intertidal marine sediments. Applied and Environmental Microbiology, 1985. 50(1): p. 81-90.

16. Park, K.S., et.al, Fate of PAH compounds in two soil types: influence of volatilization, abiotic loss and biological activity. Environmental Toxicology and Chemistry, 1990. 9: p. 187-195.

17. Dzombak, D.A. and R.G. Luthy, Estimating adsorption of polycyclic aromatic hydrocarbons on soils. Soil Science, 1984. 137(5): p. 292-308.

18. Weissenfels, W.D., H.J. Klewer, and J. Langhoff, Adsorption of polycyclic aromatic hydrocarbons (PAHs) by soil particles: influence on biodegradability and biotoxicity. Applied Microbiology and Biotechnology, 1992. 36: p. 689-696.

19. Manilal, V.B. and M. Alexander, Factors affecting the microbial degradation of phenanthrene in soil. Applied Microbiology and Biotechnology, 1991. 35: p. 401-405.

20. Pignatello, J.J., Sorption Dynamics of Organic Compounds in Soils and Sediments, in Reactions and Movement of Organic Chemicals in Soils, B.L. Sawhney and K. Brown, Editor. 1989, Soil Science Society of America: Madison, Wisconsin. p. 45-80.

21. Ripp, J., Data:Courtesy of Atlantic Environmental Services, Inc. 1993, Atlantic Environmental Services, Inc.:

Address Reprint Requests to:

Jon S. Ginn

Utah Water Research Laboratory

1600 East Canyon Road

Logan, UT 84322-8200 